\title{
16
}

\section{UKRAINE IN THE PROMOTION SYSTEM FOR EXPORTS OF HIGH-TECH PRODUCTS}

\begin{abstract}
The world experience of state promotion of high-tech exports is investigated, which involves the use of multifactorial legal, financial and insurance instruments. First, it is established that the country is not able to fully integrate into the world economic space and effectively develop without the development of high-tech exports. Secondly, it has been found that owning high-tech products in the context of globalization is becoming an extremely important factor in gaining competitive advantage in world markets, thus, national producers should rely on government assistance in the form of adequate risk coverage and various financing schemes. Thirdly, it is confirmed that Ukraine will be able to develop the system of state support for exports by expanding and improving the efficiency of existing state bodies, as well as creating institutional frameworks for the implementation of new mechanisms - the National Export Development Strategy of Ukraine.
\end{abstract}

(C) Anatoliy Rybchuk, Taras Bachynsky, 2020.

Rybchuk Anatoliy, Doctor of Economic Sciences, Professor at the Department of Economics and Management, Drohobych Ivan Franko State Pedagogical University, Ukraine. ORCID: https://orcid.org/0000-0002-5130-2442 Email: rav957@ukr.net.

Bachynsky Taras, PhD student at the Department of Economics and Management, Drohobych Ivan Franko State Pedagogical University, Ukraine. ORCID: https://orcid.org/0000-0002-4394-2597 Email: frossinone@gmail.com. 


\section{Key words:}

State incentive, export, high-tech products, competitive environment, world markets, export development strategy.

JEL: F13, O24, O38.

\section{Literature review and problem statement}

In the context of further globalization of the world economy and the deepening international division of labour, export of high-tech industrial products is gaining importance and becoming one of the priorities of Ukraine's economic policy. The high-tech industry forms the basis of world export. The experience of leading countries and major industrial corporations shows that full integration of the state into the world economic space and its effective development is impossible without the development of export of the country's industrial products. Therefore, achieving the priority objective of accelerated growth of the Ukrainian economy is impossible without state support of high-tech innovative industries and increase in the export of scientific products to the world market.

Both Ukrainian and foreign scientists research the problems of state stimulation of high-tech exports. This is due to the fact that in modern conditions the system of state support for export of high-tech products is an important direction of trade policy of many developed and, in recent years, developing countries. Moreover, each country develops its own foreign economic policy in order to maintain its competitive position in the global technology market (National Export Development Strategy of Ukraine, 2017). In fact, there are different approaches among scientists regarding the directions of each state's conduct in the foreign economic decision-making. The analysis of the experience of developed countries finds a general recommendation at the initial stage of improving the hightech sector. «lt is recommended to highlight the high-tech priority industries and to focus on their development. State support for priority high-tech industries needs to be strengthened and their funding encouraged» (Pryvarnikova, 2012). One of Ukraine's urgent issues is attracting foreign investors involved in hightech production so that state-of-the-art experimental production can be intro- 
duced in the country. Foreign investments in tangible and intangible forms into innovation are an important factor for stimulation of innovative processes and formation of territorial innovative potential (Babaiev, 2018). The Export Strategy of Ukraine (the «road map» of strategic trade development) for 2017-2021 established that modern Ukrainian exports consist mainly of intermediate goods with relatively low technological component - the share of high-tech exports in 2015 accounted for only 5.5\% of total Ukrainian exports (Matiushenko, 2018). Although high-tech products are part of the commodity structure of Ukrainian exports, their volumes are insignificant. The analysis of the export and import volumes of certain Ukrainian high-tech products makes it possible to state that the majority of the studied commodity groups have a negative trade balance, except for the exports of aircraft and spacecraft. Insufficient coverage of high-tech imports by its exports leads to technological backwardness and dependence of Ukraine on developed countries, which export outdated technological achievements to Ukraine and receive financial resources for their own further development and research. (Pichkurova, 2017). State support for the export of high-tech products in Belarus provides for the promotion of high-value-added knowledgeintensive and high-tech exports, which is one of the main tasks of foreign trade development (Nikitina, 2013).

\section{Aim of the article}

To analyse the experience of developed countries and transition economies in formulating national strategies for supporting exporters of modern technologies and to propose a system of tools for facilitating the entry of Ukrainian high-tech products into foreign markets.

\section{Research methods}

Methods of analysis and synthesis, induction and deduction, economic and statistical method, including grouping and comparison were used in the research process. The widespread use of the systematic method in tandem with the induction method made it possible to generalize the foreign experience of the hightech market's operations, as well as to determine the tendencies of its development taking into account the participation of Ukrainian manufacturers of modern technologies. Conceptualisation of the systematic operations of the world market of modern technologies was carried out using the abstract-logical method of economic research. 


\section{Research results}

The formation of a global technology market is the most important qualitative change in the system of world economic relation of the recent decades. In an era of rapid international scientific and technological development, the role of technology as a factor of economic growth has significantly increased. Owning high-tech products in the context of globalization is becoming an extremely important factor in gaining competitive advantage on world markets. This increases the importance of technology as a commodity in world trade, resulting in the high dynamics of the global technology market and its impressive scale. (Oakey, 2012):

Currently, three approaches are being used to identify high-tech products

- sectoral: by type of economic activity, where the key criterion is the degree of implementation of modern technologies and scientific developments in the production process;

- commodity: by final product and its knowledge-intensity (based on the Standard International Trade Classification - SITC), broken down into 9 groups;

- patent: by high-tech patents (based on International Patent Classification).

In international statistics, «high-tech products» refers to the gross output of the following groups of industries (Matiushenko, 2018): aerospace industry; radio-electronic industry, production of computers, office equipment and software, as well as the communications industry; medical equipment, precision and opticelectronic equipment; chemical and pharmaceutical industry.

Recent years show that exports of high-tech industries on the world market have increased by more than 2.2 times. Globally, there was an increase of $18 \%$. The leading countries in 2016 included China with 25\% (496 billion USD), Germany - 10\% (189.6 billion USD), USA - 8\% (153.1 billion USD), Singapore - $6 \%$ (126.3 billion USD), South Korea - 6\% (118.4 billion USD). A longer list is shown in Figure 1.

One of the most powerful national government export promotion systems was established in the US, which has been at the top of the list of exporting countries for many years. Exports in 2016 amounted to 1.46 trillion USD there. The main institution of state support for exports in the US is an independent government agency - Export-Import Bank of the United States (US EXIM bank). Its purpose is to provide financial assistance and stimulate the export of American goods. The value of exports stimulated during the studied period peaked in 2012 when it amounted to 49,988.9 million USD. Further amounts allocated to loans, 
guarantees and insurance, were gradually reduced. As of 2016, this amount was one of the lowest yet and amounted to 5,037.1 million USD. This phenomenon may well be systemic and may be related to the overall decline in US business activity compared to prior periods. Since 2016, stimulated exports totalled at $8,039.4$ million USD. Given that total US exports amounted to 1.46 trillion USD, the share of exports stimulated by the US EXIM bank amounted to only $0.6 \%$ (Export-Import Bank of the United States, 2018).

Fig. 1

\section{Top 10 high-tech export countries in 2016 (billion USD and \%)}

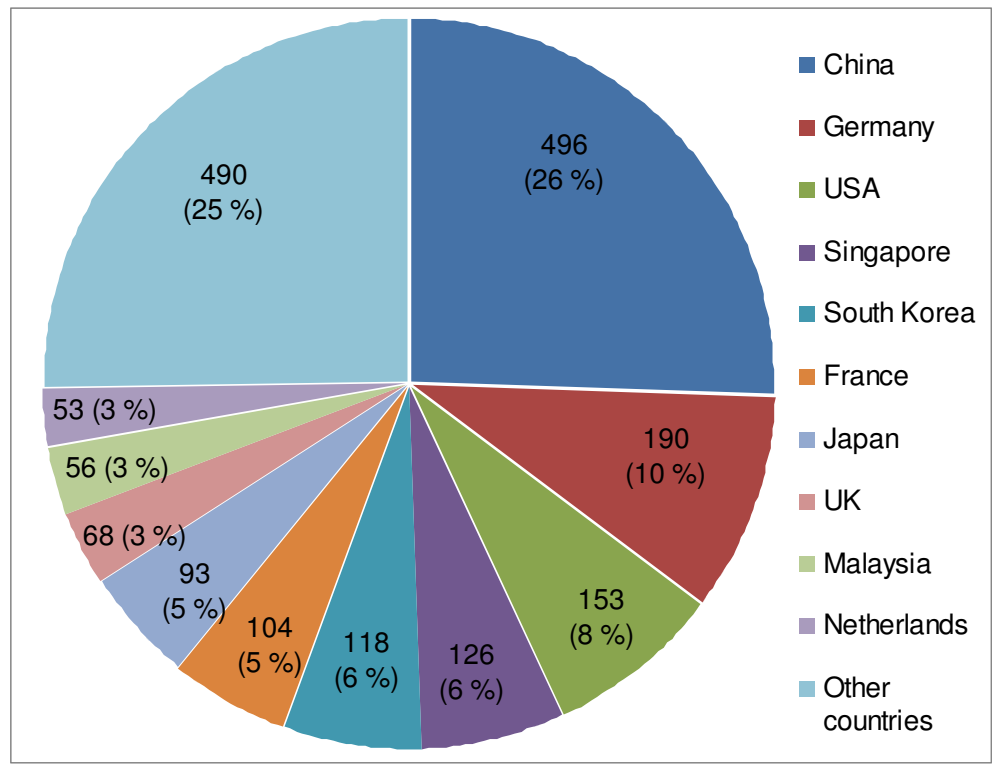

Source: World Trade Statistical Review (2018).

Support for small and medium-sized enterprises plays an important role in the US export promotion system. Thus, in 2016, 2,677.4 million USD was allocated to support them, accounting for $53.15 \%$ of the total allocated funds. The US EXIM bank constantly develops and offers new products to support the export activity of small and medium-sized enterprises. For example, Global Express Credit was specifically designed to provide short-term capital loans, making exporters eligible for a 6- or 12-month renewable line of credit of up to 500,000 USD. Another great 
product for small businesses is Express Insurance. The product simplifies the access of small business exporters to credit insurance of their export earnings, facilitates obtaining financing in case of book debts (Science and Engineering Indicators, 2018).

Overseas Private Investment Corporation (OPIC) and the Trade and Development Agency (TDA). OPIC assists US companies by providing and securing loans for medium- and long-term investments abroad (in developing and CIS countries) (Pichkurova, 2017). TDA assists developing countries with economic growth while allowing US companies to enter their markets with the ultimate goal of creating jobs in the US. Neither OPIC, nor TDA credit the exporters directly. Their main activities revolve around stimulating private investment in developing countries.

Indirect export promotion measures in the United States also include the granting of tax benefits. However, this measure of export promotion is used sparingly. The Generalized System of Preferences is much more interesting, as it allows certain countries to import products into the US duty-free. This practice not only aims to stimulate the import of scarce raw materials, but also puts pressure on these countries to promote their own products.

Non-financial support measures are an important element of the US export promotion system. Among them are trade-political, information-consulting, promotional activities, moral support for exporters. As a rule, a specialized export support agency - the US Department of Commerce's International Trade Administration (ITA) - deals with these issues. ITA provides great assistance to exporters by their annual participation in more than 100 foreign trade shows and more than 20 trade shows organized in the country to invite potential foreign buyers. In addition, it has established business information services by region, in particular the countries of Central and Eastern Europe.

The experience of the People's Republic of China (PRC) deserves special attention. China's economic development rates in recent years have been rather high, as have the rates of export growth: in the period since 2005, China's export volume has increased by $175 \%$ and reached 2.098 billion USD in $2016 \mathrm{com}$ pared to 761,953 million USD in 2005 (UNCTAD, 2018). Having analysed China's experience in export promotion, we must note that China's accession to the WTO in November 2001 played a significant role. In 2004, the Law on Foreign Trade that regulates the foreign economic activity of the PRC was substantially updated. In order to better develop foreign economic activity and bring it into line with WTO norms, the regulations of foreign economic activity have been changed and the directions of state support measures for exporters have been determined (Yaremchuk, 2016).

The Export Credit Agency (ESA), main export support institution in the PRC, is divided into two parts - the Export-Import Bank of China (CEXIM) and the China Export and Credit Insurance Corporation (SINOSURE). The main goal 
of CEXIM is to promote the export of mechanical and electronic equipment, new and high-tech products of Chinese enterprises. The main objective of SINOSURE is to promote the export of high-tech products and high value-added goods. Another funding provider is the China Development Bank, which annually allocates about 10 billion USD for medium- and long-term export financing (Panchenko, 2016).

Since SINOSUREls establishment, the guarantees on export credits insured by this organization ranged from $0.8 \%$ to $1.1 \%$ of China's GDP per year. The volume of export credits issued by CEXIM has been consistently about $0.5 \%$ of the country's GDP. Thus, the total state financing of export in the country is about $1.3 \%-1.6 \%$ of GDP per year. This figure is quite impressive, as according to the Berne Union, on average, developed countries spend $0.35 \%$ of GDP per year on financial support for exports. (Odotiuk, 2011).

Currently, the main measure of exports promotion in the Republic of Belarus is provision of financial support in the form of export credit and export risk insurance. A key document in the field of export crediting and export risk insurance through state support is the Decree of the President of the Republic of Belarus of August 25, 2006 No. 534 «On Promoting the Export of Goods (Services)» (hereinafter - Decree No. 534). According to this decree, it is envisaged to create a national integrated export promotion system - a set of mechanisms of financing and insurance of foreign trade operations against political and commercial risks. However, from the point of view of separate ECAs, there is only one entity in the country - the Beleximgarant Belarusian Republican Unitary Export-Import Insurance Enterprise (hereinafter - Beleximgarant), which has the exclusive right to provide export insurance on behalf of the Republic of Belarus. Beleximgarant was founded in 2001 by the Council of Ministers of the Republic of Belarus. The main task of Beleximgarant is providing state support for export insurance (Nikitina, 2018).

The share of national exports covered by insurance in 2016 amounted to $1.85 \%$, which is far behind the global trends in export risk insurance. As for export crediting, there is no specialized export-import bank (hereinafter - EXIM bank) in the Republic of Belarus, so exporters have to apply to the country's commercial banks for a loan.

The main areas of export financing are automotive machinery and components $(27.0 \%$ of export loans), dairy products $(26.6 \%)$, road marking machines and materials (20.3\%). In 2016, the DBRB granted a total of 87 million USD in export loans. However, the DBRB does not fully specialize in export crediting because its operations are rather diversified. The share of export credits in 2006 was $16 \%$ of all loans issued by the bank throughout that year. Therefore, it is premature to say that the DBRB can be transformed into a full-fledged exportimport bank. 
International leasing is also used as a financial support tool for export in the Republic of Belarus. Promagroleasing OJSC has been authorized to create and implement an international leasing mechanism to promote Belarusian products to foreign markets in 2009, in accordance with the Decree of the Council of Ministers of the Republic of Belarus No. 1505 of November 19, 2009. Since 2010, projects of supplying Belarusian equipment on leasing terms have begun being implemented. Promagroleasing works with large and medium-sized Belarusian enterprises engaged in the production of agricultural goods, road machinery, lift equipment, trucks and their parts, and a number of instrument-making factories. It should be noted that the use of international leasing as a method of stimulating exports is quite promising. Diversification of financial services will promote competition in this area and, accordingly, reduce the interest rate (Babaiev, 2018).

At present, the technological advancements in Ukraine are slow going, which shows in the share of our country in the world high-tech production is $0.1 \%$, according to Science and Engineering Indicators. World Bank data on the share of exports of high-tech products in total Ukrainian exports indicate that, since 1996, high-tech exports have been growing erratically and did not tend to increase steadily. The highest growth rates were observed in 2003, 2012, 2014 and 2015. According to this indicator, Ukraine $(7.27 \%)$ is inferior to such countries of the post-Soviet space as Estonia (10.5\%), Kazakhstan (41.1\%), Kyrgyzstan (11.8\%), Latvia (15\%), Lithuania (11.8\%), and Russian Federation $(13.7 \%)$. The gap in values of this indicator is even bigger observed between Ukraine and developed countries; in particular, in the USA it is $20 \%$, in Japan $16.4 \%$, in Germany $-16.6 \%$, in France $-26.8 \%$, etc. The lack of a tendency towards steady growth of high-tech exports indicates that a clear strategy for technological development of Ukraine and mechanisms of its implementation must be developed. (Science and Engineering Indicators, 2018).

Table 1

Dynamics of Ukrainian export of high-tech goods in 2002-2020, million USD

\begin{tabular}{|l|c|c|c|c|c|c|c|}
\hline \multicolumn{1}{|c|}{ Commodity Groups } & 2002 & 2004 & 2005 & 2008 & 2010 & 2015 & $\begin{array}{c}2020, \\
\text { forecast }\end{array}$ \\
\hline Pharmaceutics & 5,8 & 11,4 & 17,5 & 38,4 & 46,8 & 87,0 & 99,8 \\
\hline Aerospace engineering & 177,7 & 196,4 & 245,3 & 387,0 & 547,8 & 798,0 & 888,6 \\
\hline $\begin{array}{l}\text { Computer and office } \\
\text { equipment }\end{array}$ & 5,3 & 82,9 & 17,6 & 32,1 & 36,6 & 98,0 & 114,9 \\
\hline $\begin{array}{l}\text { Electronics and tele- } \\
\text { communications }\end{array}$ & 93,4 & 325,7 & 87,3 & 523,4 & 249,1 & 469,9 & 493,3 \\
\hline Scientific devices & 129,9 & 519,8 & 100,9 & 136,6 & 149,7 & 252,4 & 286,2 \\
\hline Total & 412,1 & 1136,2 & 468,6 & 1117,5 & 1025,0 & 1705,3 & 1882,8 \\
\hline
\end{tabular}

Source: (Yaremchuk, 2016). 
Ukraine will be able to develop the system of state support for export by expanding and improving the efficiency of the existing state bodies, as well as by creating institutional basis for the introduction of new mechanisms that the state can use for these purposes. (Matiushenko, 2018). There are numerous organizations of various levels in the state bodies supporting export activity of Ukrainian enterprises. The Ministry of Economic Development and Trade of Ukraine is a leading body in the system of central executive bodies for the implementation of the state foreign economic policy. Sectoral central executive bodies are the institutions that formulate state policy to support export of enterprises in the relevant sectors of the Ukrainian economy. Regional (oblast, local) authorities also play a part. Joint-Stock Company "State Export-Import Bank of Ukraine» is a stateowned bank whose purpose is to create favourable conditions for economic development and support for domestic producers, to provide credit and financial support for structural adjustment processes, to strengthen and utilise the production and trading potential of economic sectors (mainly export-oriented and importsubstituting ones) (Kozak, 2011).

The importance of ECA in supporting the export activity of enterprises is evidenced by the data of the International Union of Credit and Investment Insurers (Berne Union), which brings together all the major ECAs in the world. According to their data, during the period of the global economic crisis in 2008-2009, the members of the Berne Union paid out insurance claims in the amount of 128 million USD to foreign companies due to non-payment by Ukrainian buyers (Yaremchuk, 2016).

\section{Conclusions}

Thus, the experience of the countries that have developed a sufficiently effective policy of supporting high-tech exports and neighbouring countries that formulate and search for appropriate instruments to stimulate the implementation of high technology in the world markets positively contributes to the Ukrainian efforts of implementing adequate measures aimed at ensuring the development of national high-tech production. The use of foreign policy instruments can also be considered a feasible measure of state support for exports. For this purpose, it is necessary to create a "green corridor» for national exporters of high-tech products, which would provide for simplification of customs administration and improvement of currency and export control, thus increasing the competitiveness of Ukrainian manufacturers on world markets. 


\section{References}

1. Babaiev V. (2018). Targets of state regulation of innovative activity`s financial support. State Formation, 2, pp. 1-11. (in Ukrainian).

2. Export-Import Bank of the United States. (2018). Annual Reports, 78 p.

3. Kozak L., Fedoruk O. (2017). Conceptual bases for implementation of the National Export Development Strategy of Ukraine. Economics and Transport Management, 5, pp. 41-54. (in Ukrainian).

4. Matiushenko I. (2018). Practical aspects of definition of high-tech industries in Ukraine. Social Economics, 55, pp. 37-48 (in Ukrainian).

5. National Export Development Strategy of Ukraine as of 25.05.2017. (2017). Retrieved from: http://ukrexport.gov.ua/ukr/zed/strategy/ukr/4589.html (in Ukrainian).

6. Nikitina E. (2013). Development of the enterprise export potential: products promotion to foreign markets. State and regions. Series: Economics and Business, 1 (70), pp. 211-215. (in Ukrainian).

7. Oakey R. (2012). High-Technology Entrepreneurship. Paris, Recherche, 208 p.

8. Odotiuk, I. (2011). High technology domestic industry: knowledge, innovation, investment factors of its formation and development. Visnyk of the National Academy of Sciences of Ukraine, 11, pp. 21-33. (in Ukrainian)

9. Panchenko Ye., Voichak M. (2016). State support for high-tech exports: a comparative analysis and lessons for Ukraine. The Journal of International Economic Policy, 2 (25), pp. 99-125. (in Ukrainian)

10. Pichkurova Z. (2017). High-tech component of Ukrainian exports in the conditions of global competition. Strategy of Ukraine. Economics, sociology, law, 2, pp. 84-91. (in Ukrainian)

11. Pryvarnykova I., Kostiuchenko M. (2012). Development of the high technology sector of the Ukrainian economy. Marketing and Management of Innovations, 2, pp. 45-52. (in Ukrainian)

12. Science and Engineering Indicators. (2018). 635 p.

13. United Nations Conference on Trade and Development. (2018). General Profile: China, Retrieved from: http://unctadstat.unctad.org/CountryProfile/ GeneralProfile/en-GB/156/index.html

14. World Trade Statistical Review. (2018). 210 p.

15. Yaremchuk, N., Hrynko, I. (2016). Analysis of foreign trade in high-tech goods of Ukraine. Uzhorod National University Herald. International Economic Relations And World Economy, 6(3), pp. 171-174. (in Ukrainian). 